\title{
John Dewey's Instrumentalism and Techno-Scientific Development: Its Implications to Man and Society
}

\author{
Raphael Olisa Maduabuchi, Eugene Anowai \\ Department of Philosophy, Chukwuemeka Odumegwu Ojukwu University, Igbariam Campus, Anambra, Nigeria \\ Email: maduabuchiolisa@yahoo.com
}

How to cite this paper: Maduabuchi, R. O., \& Anowai, E. (2018). John Dewey's Instrumentalism and Techno-Scientific Development: Its Implications to Man and Society. Open Journal of Philosophy, 8, 549-556. https://doi.org/10.4236/ojpp.2018.85038

Received: August 7, 2018

Accepted: November 24, 2018

Published: November 27, 2018

Copyright $\odot 2018$ by authors and Scientific Research Publishing Inc. This work is licensed under the Creative Commons Attribution International License (CC BY 4.0).

http://creativecommons.org/licenses/by/4.0/

\section{(c) (i) Open Access}

\begin{abstract}
This work sought to examine the implications of John Dewey's instrumentalism on techno-scientific development. Instrumentalism is John Dewey's aspect of pragmatism. Dewey's idea of pragmatism is anthropomorphic naturalism. Anthropomorphic naturalism is an argument for a reconsideration of the place of man in the world through some adjustments in the practice of science. In the view of John Dewey, scientific findings have extended the confines of man as an end in itself. Dewey was convinced that there is a gap between the desire to improve man's wellbeing through scientific discoveries and inventions and the commitment to ensure that these improvements do not consistently threaten the well being of man and his environment. This referred to as abysmal gap between the theory of science which focuses on the wellbeing of man and his environment, and the practice of science which ignores this wellbeing in the long term. Thus, a question deserves our attention: "Do we continue with this 'pull' to discover and invent, even to our own detriment while ignoring the evident fact that this 'pull', when not monitored by values and principles, portend danger for mankind as fictitiously represented in Frankenstein's monster?" The aim of this study is to examine the relationship between the theory of science which focuses on the wellbeing of man and environment, and the practice of science which ignores this wellbeing in the long term. His idea of anthropomorphic naturalism draws attention to the need to integrate values into the practice of science. This work posits that Dewey's pragmatic or humanistic naturalism offers a solution to the existing paradox of advancement for self harm or destruction.
\end{abstract}

\section{Keywords}

Instrumentalism, Anthropomorphic, Naturalism, Science, Theory, Practice and Environment 


\section{Introduction}

Pragmatism is the outcome of scientific revolution. Modern scientific age is characterized by an absolute reliance in human capacity to know by modern scientific method and the ability to control the world by application of scientific knowledge in technology. But, the modern practice of science has reduced the state of man as the general physical scheme of things. There is the need to integrate values into science. One of the important problems confronting philosophers and scientists is the problem of values known as axiology. Stressing on this view point, Okafor (2010) conceived thus: "The factor of valuing is an inevitable consequence of man's rationality which determines a whole lot of human conduct... They are the basic understructure in all matters of choice and decision making".

In this modern era, scientists have invested so much effort on physical value of applied science and technology which resulted to tremendous inventions in human society. Explorations and advancements in modern science have enabled human beings to attain improved standard of living. At the same time contributed in the development of dangerous nuclear and chemical weapons, the spread of pollutants threatening the future of human lives, and weakening of our ozone layers. However, the goals of scientists are sometimes opposing and conflicting with value of human life. In view of John Dewey, scientific findings have extended the confines of man as an end in itself.

John Dewey put up his theory of pragmatism. Dewey's pragmatism is geared towards humanistic naturalism which offers an argument for a reconsideration of the place of man in the world through some adjustment in the practice of science. Hence, Dewey's pragmatism contravenes the scientific realism which upholds that physical theories are the best account of reality. Dewey, thereby, criticizes a society that limits science to physical matter. In such a society, according to him, knowledge is divided against itself, for the human disciplines are separated from physical sciences (Eldridge, 1998). This allows technology to play its part in generating enslavement of men, women and children in factories in which they are animated machine to tend inanimate machines.

On the other hand, Dewey's philosophy is a cultural instrumentalism which tends to situate thought within society and history. In this regard, Dewey (1929) envisaged that science is to be integrated into the realm of values when it is used to bring about the things we value. Scientific explorations should be geared towards solving human problems in the society. Dewey thought that philosophy would come unto its own when it paid attention to human problems in the society by improving the intellectual tools used by human to solve their problems. Thus, Dewey's pragmatic instrumentalism can serve as a sole model of practicing science in the advanced economies of Europe and America as well as developing countries of Africa.

\section{Conceptual Clarification of Basic Terms}

The key concepts that are associated with this study are: instrumentalism and 
techno-scientific development. Instrumentalism is used synonymously with pragmatism or experimentalism. Instrumentalism links knowledge with action.

According to English Oxford Living Dictionaries (n.d), "instrumentalism is a pragmatic philosophical approach which regards an activity (such as science, law, or education) chiefly as an instrument or tool for some practical purpose, rather than in more absolute or ideal term." John Dewey characterized his pragmatism as instrumentalism. Instrumentalism is the pragmatic philosophy of John Dewey which maintains that thought, theories and concepts are instruments for solving practical problems.

On the other hand, techno-scientific development deals with developments in modern science and technology. Technoscience is a terminology which conceives that science and technology are relational (Technoscience-Cyborg Anthroplogy, n.d.). In other words; scientific knowledge is used to solve technical problems and vice versa. This new practical trend started in scientific and industrial revolutions of modern period when scientific knowledge is applied for technical purpose in industry. John Dewey's theory of inquiry envisages that scientific knowledge is geared to solve the problematic situation of lives in the society.

\section{Theoretical Framework}

This work is anchored basically on Charles Darwin theory of evolution. Charles Darwin's theory of evolution is a revolt against the conservative world view of religion. Darwin published the most significant work in the history of science: The Origin of Specie on the basis that living things are engaged in a struggle for survival, which is sometimes crudely described as a matter of eating without being eaten (Darwin, 1979). The struggle for survival implies that those individuals that possess greater speed, olfaction, sight, agility, élan, fan and so on than other animals with which they must compete will be likely to have progeny in greater numbers than those less competitive individuals. Those species of animal with traits suited for survival would grow up and reproduce offspring with those traits. Eventually, new specie would descend from common ancestors. His theory of evolution by natural selection implies that species of the new offspring becomes better and better adapted to the environment in which its members must survive. For evolution to evolve, there must be variation within the members of the species in a given environment who are able to replicate themselves and who are under survival pressure, which means that those individuals who possess characteristics that give them a competitive advantage will be selected by means of the competition in a struggle for existence.

The intellectual tradition of Copernican revolution gave men free scientific inquiry in the vicissitude of nature. This inquiry led Charles Darwin to postulate his famous evolutionary theory as the springboard for revolution in biology, religion and philosophy. Charles Darwin theory of evolution by natural selection became the foundation of modern evolutionary studies. Hence, Darwin's theory of evolution was made the generalization of all scientific method as well as the 
key defining nature to explaining mind and society. According to Popp (2007), John Dewey saw in Darwin thesis the basis for developing a naturalized theory of meaning. Dewey's appeal to evolution as a basis for developing a naturalized theory of meaning was an appeal to the most comprehensive of scientific theory, one supported by evidence from numerous and divergent scientific fields. The pragmatic emphasis on change is derived from daily routine of the facts of life in nature. Dewey (1965) envisaged that the scene of nature which directly confronts us is in flux, and nature as directly and practically experienced does not satisfy the conditions of knowledge. Thus, he expressed that the appropriate objects and organons of knowledge are found in the mutual interactions of changing things. The influence of Darwin upon philosophy has established a new phenomenon of life, thereby, emancipated genetics and experimental ideas as an organon of asking questions and looking for explanation.

On the contrary, many attacks on Darwin's idea came from religious opponents whose the ologico-cosmological views of the world were defeated in renaissance period. They thought that evolution denied the divine creation of human beings and made people and animal equal. Many scientists did not believe Darwin's theory of evolution until modern genetics began in early 1900. An Austrian monk named Gregor Mendel experimented with pea plants in 1860s. One of the things, or traits, Mendel studied was what makes some pea plant tall and some short. He discovered that the traits must come from units of heredity passed from the parent plants to offspring. However, pragmatism is based on Charles Darwin's theory of evolution by natural selection in The Origin of Species.

\section{John Dewey's Anthropomorphic Naturalism}

John Dewey's pragmatic naturalism is not a materialistic naturalism which strips nature of all qualities that give it meaning and purpose. On the other hand, Gale (2008) envisaged that Dewey's pragmatic naturalism is anthropomorphic or humanistic naturalism which eschews any bifurcation between man and nature. In this sense, nature is geared to serve human needs. Hence, Dewey's naturalism has to do with biological behaviouralism. John Dewey depicts the relationship between man and nature. Man interacts with his environment to achieve a richer harmony with it. The harmonious association of experience and nature is a situation whereby experience presents itself as a method for getting at nature, penetrating its secrets, and where in nature empirically disclosed deepens, enriches, and directs the further development of experience (Dewey, 1929).

His philosophy presents an empirically based description of experience. It conceives that nature is experienced as an event which displays a combination of precarious and stable, settled and unsettled, determinate and indeterminate aspects (Dewey, 1929: p. 35). So, every existent is perceived as being related to problematic situation. Camus (1955) conceived this problematic situation of life as absurdity of human existence. The inquirer is preoccupied with what can be done at this point to resolve the problematic situation in life. It contravenes 
against argument of design. Dewey criticizes this ideology. According to Dewey (1934), supernaturalism especially the claim that religions have a monopoly of supernatural means to further human development is an obstacle in pursuing the natural changes that are in human power to bring about. In this case, ideal world is separated from the factual world of human experience. This mindset is responsible for the existing crisis between science and religion.

\subsection{John Dewey's Pragmatic Theory of Knowledge}

Dewey's theory of knowledge is a change against the old system which separates knowledge from existence. Dewey's instrumentalism relates knowledge to action or theory to practice. He lamented that the main problem of philosophy is the separation of theory from practice. Science is to be integrated into the realm of values in order to overcome the separation of theory from practice. On the contrary, the conservative worldview promotes spectator theory of knowledge, which separates knowledge from overt action. In this sense, knowledge is fixed and immutable.

However, this spectator theory of knowledge has to be relaxed by a theory that regards the knower as an intelligent agent who acts on his environment to change contingencies in nature. Hence, knowledge serves as the offshoot of inquiry as in the case of experimental science. In his theory of inquiry, Dewey (1938) portrayed that thinking would not exist, and hence knowledge would not be found, in a world that presented no trouble. In other words, every inquiry is prompted by doubt, which requires problem solving method to tackle the situation. Dewey is committed to the scientific thesis that all knowledge is acquired through scientific method. Thus, Dewey (1910) postulated that the experimental method of science is characterized into five stages:

1) a felt difficulty; 2) its location and definition; 3) suggestion of possible solution; 4) development by reasoning of the bearings of the suggestion; 5) further observation and experiment leading to its acceptance or rejection...(p. 72)

A felt difficulty is experienced when man interacts with his environment. Certain problems do emanate as man interacts with his environment. The problem has to be located and defined. Understanding of the problem leads to suggestion of a possible hypothesis. Hypothesis is assumed or intelligent guess which presents the tentative solution to the problem. Hence, the hypothesis has to be examined to ascertain its reliability. Finally, it has to be experimented for its acceptance and rejection. If the accepted hypothesis works, new knowledge is acquired. This knowledge is not absolute because all knowledge is to be subjected to constant revision. Relativism is at heart of the scientific philosophy. Thus, the pragmatists hold that truth and knowledge are tentative i.e. they are valid as long as they continue to work out in experience with the course of man's transaction with nature. 


\subsection{Implications of John Dewey's Instrumentalism on Scientific Discovery}

Scientific and technological inventions arise when a society has an unfulfilled need. Indeed, the recent scientific inventions of his time tend to buttress Dewey theory of inquiry in the sense they tend to satisfy human needs. For instance, the need for people to cool and preserve their food led to the invention of refrigerators and freezers. Thus, science and technology have transformed human society enhancing better living condition of people in the modern world.

Dewey's anthropomorphic or humanistic advocates that scientific discovery is geared to serve human essence. Scientific innovations that were inimical to the well being of man should not be promoted. It is evident that Dewey's instrumentalism is not a proto-positivist who sought to reduce meaning to scientific procedure. Hence, Dewey uses the metaphor of modern man as a child to analyse the devastating effects of thoughtless use of technology. According to this analogy, "man, a child in understanding of himself, has placed in his hands physical tools of incalculable power. He plays with them like a child, and whether they work good or harm is largely a matter of accident. The instrumentality becomes a master and works fatally as if possessed of a will of its own not because it has a will but because man has not" (Eldridge, 1998: p. 48)

Wrong use of science has resulted to the manufacture of dangerous weapons of mass destruction. The nuclear and atomic weapons are very harmful to human lives. Hence, the atomic bomb dropped on Japan during the World War II flattens building within 3 miles or 5 kilometers of the blast. Heat from the bomb caused fires and burned everything near the place it exploded. People's skin was burned as far as 11 miles which is 18kilometers from the site of explosion. People farther from the blast developed cancer and other sicknesses from the radiation months and years after the bomb explosion (Burris, 2011). Dewey's instrumentalism is, therefore, geared to accomplish the mediation between the excesses of physical theories that subjugate human lives as slaves to science and technology in this modern scientific and atomic age.

Dewey's instrumentalism is relevant for the industrialized economies to integrate value into the practice of science. Dewey opposes scientific realism which holds that physical theories are the best account of all reality to the various types of idealism which portrays the view that truth, beauty, good have "Being" beyond the temporal existence of the common sense world or the world of science (Dewey, 1929: pp. 33-36). On this note, Africa and other developing countries need pragmatic ideology to change their conservative world-views that impede freedom to radical thinking and invention. Therefore, Dewey's anthropomorphic naturalism also can serve as a model of practicing science in developing countries like Nigeria in order to transform our traditional conservative world-views that militates against scientific development. The scientific method of experimentation is embedded on pragmatic principle of workability of an idea or a theory in practice. Thus, pragmatic education is necessary for scientific development of Third World countries. It will help to bridge the gap existing be- 
tween theory and practice, thereby; it will replace the traditional spectator theory of separating knowledge from overt action.

\section{Evaluation}

Pragmatism is an interesting and attractive philosophy which has contributed so much towards the growth of modern science and technology. But, one of the loopholes of this scientific philosophy is that it lays so much emphasis on practice. Practice cannot work without theory. Theory is very important because it lays the foundation on which the practice of science is embellished. Burtt (1932) established the metaphysical foundation of science. Metaphysics can be in form of a theory on which postulate of scientific research is formed. So, both theory and practice are necessary for modern science.

However, pragmatism is devoid of metaphysical essence. In the words of Okafor (2010: p. 81) "its view that the overt phenomena are the embodiment of all reality with which man should concern himself, leaves much to be desired. This is because the experiential reality is only a fraction and not the whole of reality. To absolutely deny, or consciously ignore, the metaphysical and supernatural dimensions of reality is not an adequate philosophical approach". Metaphysics has contributed so much to the growth of science. So, science and metaphysics should serve to complement each other. Metaphysics is the groundwork of scientific knowledge.

Again, the pragmatists seem to support the relativity of truth. The consequence or pragmatic theory of truth may not provide a satisfactory answer to the question of truth in epistemology. There are other ramifications to be considered in question of truth like correspondence theory of truth, coherence theory of truth, truth on existential plans and so on are important for better understanding of truth. Since truth is the basis of epistemology, different theories of truth serve as a point of view to complement each other.

Indeed, John Dewey and other American pragmatic philosophers lay so much emphasis on scientific knowledge. But, restricting human knowledge mainly to scientific knowledge is somehow wrong because science alone may not proffer all the solutions to human problems in the society. Other forms of knowledge like revealed or mystical knowledge are important to complement human effort. So, there is the need for man to strike a balance between science and religion in his quest to understand the role of man in the universe or cosmos.

Pragmatic theory and its implication for African ideology, especially mythical dimension seem to imply that myth does not have a positive impact on development. Science is not the only factor that impacts development in human society. Myth has helped to promote the cultural values of people. Long before the invention of printing press, personal computers, the internet and other channels of communication, Africans documented their world through storytelling and oral tradition. An important part of that process was the creation of mythology, collection of stories that were created to explain a culture's origin, history and heroes. These myths allow man not only dream of great things, but to pass on 
lessons of cultural values and morality to future generation.

\section{Conclusion}

This work has examined the contributions of John Dewey's instrumentalism on techno-scientific development. It portrays philosophy as a method or working principle cultivated by philosophers for dealing with problems of man in every field of human endeavour. Dewey has left a legacy to the contemporary society considering all the implications of pragmatism to the Western and African society.

\section{Conflicts of Interest}

The authors declare no conflicts of interest regarding the publication of this paper.

\section{References}

Burris, B. (2011). Effects of Atomic Bomb on Japan during World War 2. https://prezi.com/ssmllhqzwhnm/effects-of-atomic-bomb-on-japan-during-world-war $\underline{-2 /}$

Burtt, E. (1932). Metaphysical Foundation of Modern Science (pp. 18-23). London: Routledge and Kegan Paul.

Camus, A. (1955). The Myth of Sisyphus \& Other Essays (p. 89). New York: Random House Publishers.

Darwin, C. (1979). The Origin of Species (reprinted ed., pp. 20-28). New York: Gram racy Books.

Dewey, J. (1910). How We Think (p. 72). Boston: D. C. Heath and Co. https://doi.org/10.1037/10903-000

Dewey, J. (1929). Experience and Nature (p. 2a). London: George Allen \& Unwin. https://doi.org/10.1037/13377-000

Dewey, J. (1934). A Common Faith (p. 4). Yale: University Press.

Dewey, J. (1938). Logic: Theory of Inquiry (p. 108). New York: Holt Press.

Dewey, J. (1965). The Influence of Darwin on Philosophy (pp. 5-7). Bloomington: Indiana University Press.

Dewey, J. (1929). The Quest for Certainty: A Study of Knowledge and Action (pp. 38-39). New York: Milton Balch.

Eldridge, M. (1998). Transforming Experience: John Dewey’s Cultural Instrumentalism (p. 43). Vanderbilt: Vanderbilt University Press.

English Oxford Living Dictionaries (n.d.). Definition of "Instrumentalism" in English. https://en.oxforddictionaries.com/definition/instrumentalism

Gale, R. (2008). The Naturalism of John Dewey. In M. Cochran (Ed.), The Cambridge Companion to Dewey (p. 55). Cambridge: Cambridge University Press.

Okafor, F. C. (2010). Philosophy of Education and Third World Perspective (6th ed., p. 102). Port Harcourt: Odomezie Kris \& Company.

Popp, J. A. (2007). Evolution's of First Philosopher: John Dewey and Continuity of Nature (p. xi). Albany: State University of New York Press.

Technoscience-Cyborg Anthropology (n.d.). Technoscience. http://cyborganthropology.com/Technoscience 